\title{
Swimming ability in tadpoles of Physalaemus cf. cuvieri, Scinax $x$-signatus and Leptodactylus latrans (amphibia: anura) exposed to the insecticide chlorpyrifos
}

\author{
Silva, F.L. ${ }^{1}$; Prado, I.S. ${ }^{1}$; Fraga, R.E. ${ }^{1}$; Rocha, M.A. ${ }^{1}$; Juncá, F.A. ${ }^{2}$ \& Silva, M.B. ${ }^{1}$; \\ ${ }^{1}$ Universidade Federal da Bahia, Instituto Multidisciplinar em Saúde, BA, Brasil. \\ ${ }^{2}$ Universidade Estadual de Feira de Santana, Departamento de Ciências Biológicas, BA, Brasil.
}

Received June 22, 2021; Accept August 04, 2021

\begin{abstract}
We examined the swimming abilities of tadpoles exposed to the organophosphate chlorpyrifos for $24 \mathrm{~h}$ (at concentrations of $0,1,5$ and $\left.10 \mu \mathrm{g} \mathrm{L}^{-1}\right)$. Scinax $x$ - signatus, Physalaemus cf cuvieri, and Leptodactylus latrans tadpoles were used as biological models. Our findings evidenced decreased swimming speeds in all tadpole species exposed to chlorpyrifos as compared to the control group, although with significant statistical differences only with $P$. cuvieri and $L$. latrans. Changes in swimming ability may indirectly lead to death or alter important growth and development parameters, as the reduced ability to swim can result in increased vulnerability to predators and impacts on feeding, thus altering their fitness.
\end{abstract}

Keywords: Amphibians, Chlorpyrifos, Organophosphorus insecticide, Swimming speed, Larvae.

\section{INTRODUCTION}

There is no longer any doubt concerning global declines of amphibian populations (Pounds et al., 2006; Lajmanovich et al., 2012; Daam et al., 2019). The causes of those declines are commonly attributed to environmental impacts such as: climate change, habitat destruction and fragmentation, emerging diseases, industrial pollution, and pesticides (Kiesecker et al. 2001; Lips et al., 2005; Pounds et al., 2006; Mann et al., 2009; Lajmanovich et al., 2012; Moreira et al. 2019).

Most amphibians develop in aquatic environments, which are often contaminated by agricultural pesticides from sprayed fields or derived from leaching, surface runoff, or atmospheric deposition.

Among those agricultural pesticides is chlorpyrifos, a pesticide belonging to the organophosphate family (Pena et al. , 2008) that is widely applied to agricultural crops to control various insect pests, although many non-target populations may become exposed to those dangerous contaminants (Boone \& Bridges, 2003; Yin et al. 2009; Lajmanovich et al., 2015).
Organophosphates are inhibitors of cholinesterase enzyme synthesis, which triggers adverse effects on motor activity through the accumulation of the neurotransmitter acetylcholine (ACH). Those accumulations can initially cause hyperactivity, but then uncontrollable muscle spasms or even paralysis, resulting in the death of the animals. (Colombo \& Bonfanti, 2005; Rutkoski et al., 2020; Silva et al., 2020a).

Amphibians are known to be very vulnerable to pesticides that act by inhibiting cholinesterase synthesis (Bridges, 1997; Boone \& Bridges, 2003; Boone \& Bridges, 2006; Krishnamurthy \& Smith, 2010, Salgado Costa et al., 2018; Rutkoski et al., 2020, Silva et al., 2020a, b, c), and may be exposed to various toxic compounds in different habitats during their lifetimes (Boone \& Bridges, 2003).

Behavioral studies make it possible to examine the responses of organisms to contamination by a wide variety of chemical compounds (Plaut, 2001), and tests exposing tadpoles to compounds that depress cholinesterase enzyme activity have evidenced significant reductions in their motor activities (Bridges, 1997; Paden et al, 2011; Bernabó et al., 
2011; Arcaute et al., 2012; Rutkoski et al 2020; Silva et al., 2020a) as well as effects on larval muscular integrity (Colombo \& Bonfanti, 2005) even at low concentrations, as those compounds act directly on neural transmission (Widder \& Bidwell, 2008). According to Silva et al. (2020c), the toxic effect of chlorpyrifos on amphibians can be considered species specific.

The study of behavioral endpoints can link varied physiological disorders with ecological processes $(\mathrm{Tu}$ et al. 2010). Late biomarkers are commonly used in ecotoxicological studies to examine: the effects of different pollutants concentrations on animal behavior, mortality, reproduction, and their tissues, as well as correlating the degree of exposure to their responses, thus making it possible to identify environmental problems (Venturino et al., 2003).

It is important to mention that swimming performance can also influence an animal's ability to obtain food resources, thus interfering with their fitness and making them less apt to successfully reproduce and more susceptible to predation (Relyea \& Hoverman, 2006).

From that perspective, we sought to verify the effects of sublethal exposures to chlorpyrifos on the swimming speeds of Scinax x - signatus Spix, 1824, Physalaemus cf. cuvieri Fitzinger, 1826, and Leptodactylus latrans Steffen, 1815 (Amphibia: Anura) tadpoles. The areas where those species occur are subject to intense agricultural activity, resulting in constant exposure to that product - although the effects of organophosphates on northern South America species remain largely unknown.

\section{MATERIALS AND METHODS}

\section{Test organisms}

S. x-signatus (developmental phases 39-41), P. cuvieri (developmental phases 27-39), and L. latrans (developmental phases 27-40) tadpoles were captured in different localities in the municipality of Mucugê, and agro-industrial pole in Bahia State, Brazil, and transported to the laboratory in containers with dechlorinated water.

S. $x$-signatus is distributed throughout tropical savannas in South America, inhabiting forests edges and open areas, and always close to permanent or temporary bodies of water (Andrade et al., 2010).

L. latrans is commonly found in urban areas and has shown high resistance to anthropic environmental impacts. It is widely distributed in tropical regions, and can be found in reservoirs, ponds, or other flooded environments (Ferreira \& Tonini, 2010).

P. cuvieri is widely distributed throughout South America in open environments and can be found along the sides the edge of permanent ponds (or occasionally vernal pools) (Lingnau, 2009).

Before initiating the experiments, the tadpoles were acclimated in aquariums (35 L) with dechlorinated water, following Silva et al. (2020a, b), and fed with flake feed for ornamental fish (Alcon Basic ${ }^{\circledR}$ ).

\section{Experimental design}

Three treatments were performed with different nominal concentrations of the insecticide chlorpyrifos (Klorpan ${ }^{\circledR}$ 0,0diethyl -0-(3,5,6- trichloro - pyridyl)- phosphorothioate): $1 \mu \mathrm{g}$ (C1), $5 \mu \mathrm{g}$ (C5), and $10 \mu \mathrm{g}$ (C10) of chlorpyrifos/L of water $\left(\mu \mathrm{g} \mathrm{L}^{-1}\right)$, using dechlorinated water as the negative control (CN). L. latrans was only exposed to $\mathrm{C} 10$ due to the limited number of individuals of that species available.

The insecticide concentrations used were defined based on records from aquatic environments in Brazil, especially localities with intense agricultural activities (Da Silva, 2006). We chose to evaluate concentrations below $10 \mu \mathrm{g} \mathrm{L}^{-1}$ in light of the results of Rutkoski et al (2020) who exposed Physalaemus gracilis tadpoles to chlorpyrifos concentrations of $0,11,30$ and $90 \mu \mathrm{g} \mathrm{L}^{-1}$. The chlorpyrifos solutions were prepared immediately before each experiment.

Forty tadpoles of $S$. x-signatus and P. cuvieri, and 20 $L$. latrans tadpoles were exposed to each of the pesticide concentrations as well as the water control. All exposures occurred during a 24-hour period when the tadpoles were placed individually in $800 \mathrm{~mL}$ polypropylene bottles containing the different chlorpyrifos concentrations. The water was well-oxygenated (dissolved oxygen concentration ( $\mathrm{DO}=8.2 \mathrm{mg} \mathrm{L}^{-1}$ of water), with a neutral $\mathrm{pH}$ ( $\mathrm{pH}$ 7.0-7.6).

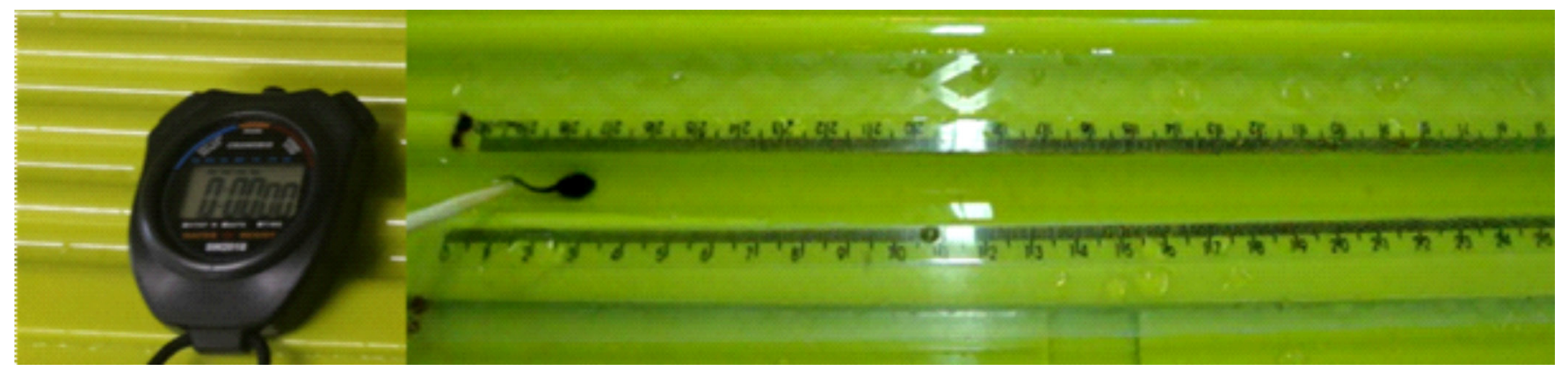

Figure 1 - Material used in the race - polypropylene lane, pipette, rulers and stopwatch. 


\section{Swimming ability and morphological abnormalities}

Following the methodology was proposed by Bridges (1997) and used by Silva et al. (2020a) for tadpoles of Odontophrynus carvalhoi: after 24 hours of exposure to chlorpyrifos (or the control) the tadpoles were individually placed in polypropylene lanes $(150 \mathrm{~cm}$ long x $3 \mathrm{~cm}$ wide x $4 \mathrm{~cm}$ deep) containing only dechlorinated water (Fig. 1). After an acclimation period of 5 minutes, each tadpole was stimulated at the base of its tail (with a pipette) to trigger a swimming response.

Tadpole swimming ability was assessed by measuring their swimming speed. The time of the swimming behavior (s) and the distance traveled $(\mathrm{cm})$ were determined using a stopwatch and graduated ruler respectively.

After the swimming test, the tadpoles were anesthetized with lidocaine, sacrificed, fixed, and then preserved in $10 \%$ formaldehyde. Morphological analyses were subsequently performed, considering the larval stage of each individual.

\section{Statistical analyses}

Analysis of variance (ANOVA) was used to determine how the chlorpyrifos treatments affected tadpole swimming speeds, comparing the averages of the speeds registered in each treatment for each species. Normality was confirmed using the modified Shapiro-Wilks test, and homoscedasticity was confirmed using Bartlett's test. Student's t-test was performed with $L$. latrans for the same purpose.

Tukey's multiple comparison test was performed to test for significant differences in the swimming speeds among tadpoles of the species $S$. $x$-signatus and $P$. cuvieri exposed to chlorpyrifos and the control. All tests were performed using GraphPad Prism 5.00 software (GraphPad Software Inc., San Diego, CA, USA).

\section{RESULTS}

The P. cuvieri and L. latrans tadpoles exposed to chlorpyrifos were slower when compared with the speed of the control group, showing significant statistical differences.

S. $x$-signatus tadpoles exposed to different concentrations of chlorpyrifos showed no statistically significant differences in swimming speed values among the different treatments $\left(\mathrm{C} 1: 8.3 \pm 3.25 \mathrm{~cm} \mathrm{~s}^{-1} ; \mathrm{C} 5: 7.65 \pm 3.84 \mathrm{~cm} \mathrm{~s}^{-1}\right.$ and $\mathrm{C} 10: 6.81 \pm$ $\left.2.5 \mathrm{~cm} \mathrm{~s}^{-1}\right)$ or from the control group $\left(8.65 \pm 2.8 \mathrm{~cm} \mathrm{~s}^{-1}\right)(\mathrm{F}=$ 0.489; $\mathrm{P}=$ 0.692) (Fig. 2).

P. cuvieri $(\mathrm{F}=18.97, \mathrm{P}<0.0001)$ and $L$. latrans $(\mathrm{T}=8.158$, $P<0.0001)$ tadpoles evidenced statistically significant slower swimming speeds as compared to the control group (14.51 \pm $8.4 \mathrm{~cm} \mathrm{~s}^{-1} ; 3.52 \pm 1.11 \mathrm{~cm} \mathrm{~s}^{-1}$ respectively) as well as among the tadpole groups exposed to different treatments: $\mathrm{C} 1(2.66$ $\left.\pm 0.9 \mathrm{~cm} \mathrm{~s}^{-1}\right), \mathrm{C} 5\left(2.24 \pm 0.82 \mathrm{~cm} \mathrm{~s}^{-1}\right)$, and C10 $(2.1 \pm 0.91 \mathrm{~cm}$ $\left.\mathrm{s}^{-1}\right)$ (Fig. 3.); L. latrans was tested only at C10 (1.30 \pm 0.66 $\mathrm{cm} \mathrm{s}^{-1}$ ) (Fig. 4.).

No morphological abnormalities were recorded.

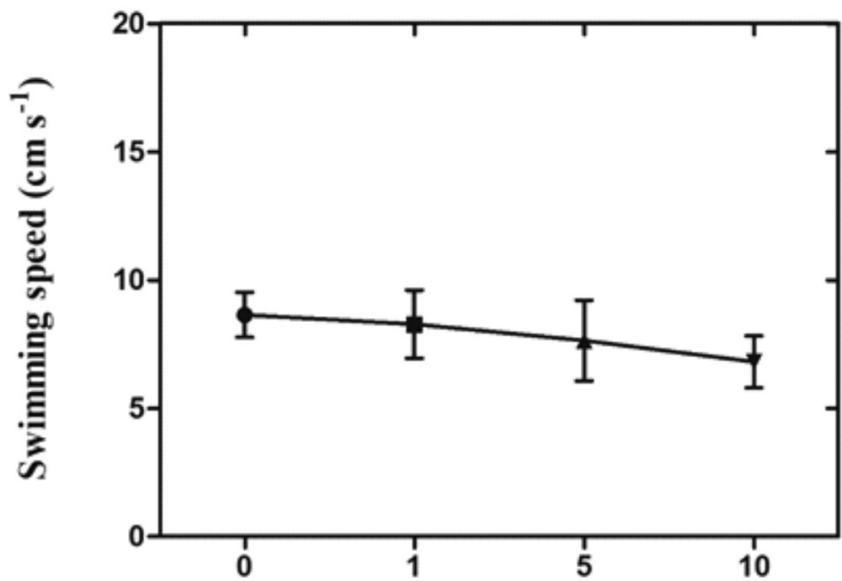

Chlorpyrifos nominal concentrations $\left(\mu \mathrm{g} \mathrm{L}^{-1}\right)$

Figure 2 - Swimming speed of Scinax $x$-signatus tadpoles exposed to chlorpyrifos $\left(0,1,5\right.$ and $\left.10 \mu \mathrm{g} \mathrm{L}^{-1}\right)$.

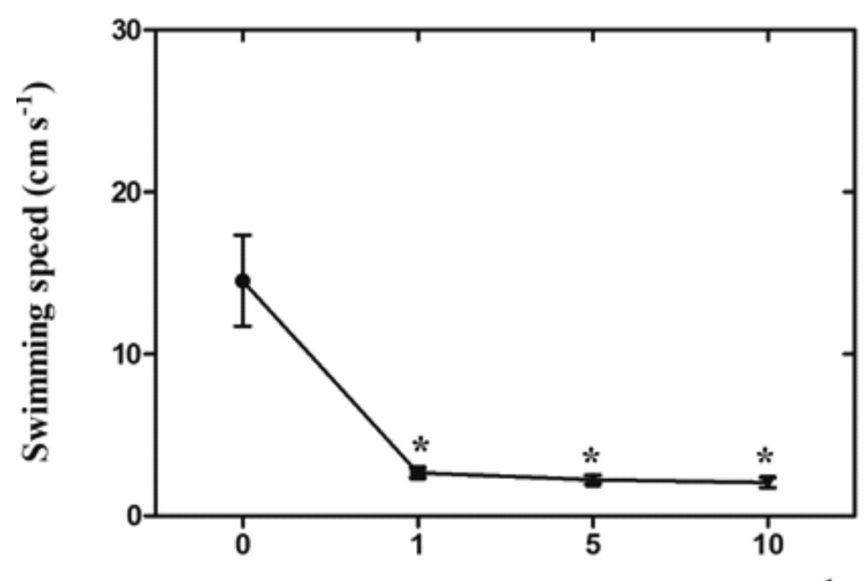

Chlorpyrifos nominal concentrations $\left(\mu \mathrm{g} \mathrm{L}^{-1}\right)$

Figure 3 - Swimming speed of Physalaemus cf. cuvieri tadpoles exposed to chlorpyrifos $\left(0,1,5\right.$ and $\left.10 \mu \mathrm{g} \mathrm{L}^{-1}\right)$. *Asterisk indicates a significant difference compared with the control group.

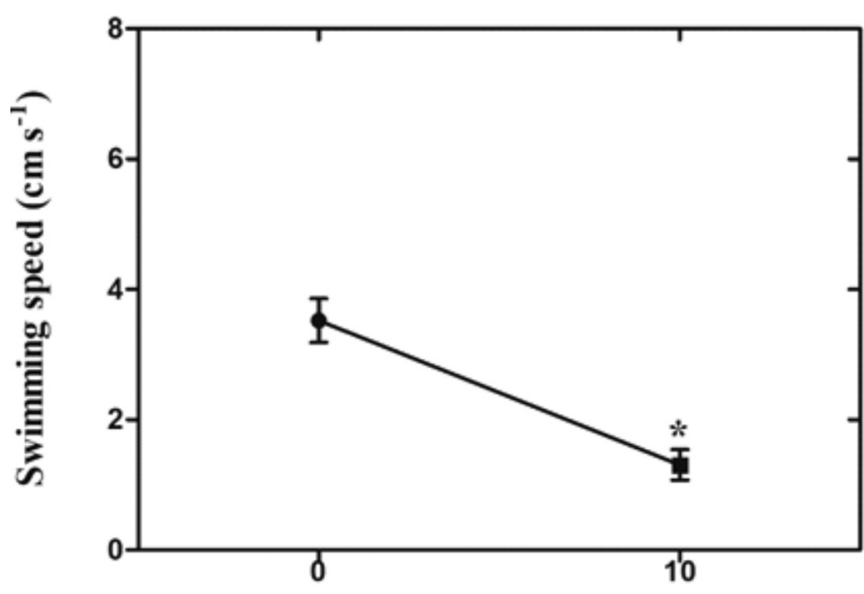

Chlorpyrifos nominal concentrations $\left(\mu \mathrm{g} \mathrm{L}^{-1}\right)$

Figure 4 - Swimming speed of Leptodactylus latrans tadpoles exposed to chlorpyrifos $\left(0\right.$ and $\left.10 \mu \mathrm{g} \mathrm{L}^{-1}\right)$. *Asterisk indicates a significant difference compared with the control group. 


\section{DISCUSSION}

We observed a significant reduction in the swimming speed of P. cuvieri and L. latrans tadpoles exposed to sublethal chlorpyrifos concentrations. No morphological abnormalities were noted, although their time of exposure to the contaminant (24 hours) was probably too short to evidence morphological alterations.

Although alterations of swimming behaviors were evident in the tadpoles of all three species exposed to chlorpyrifos, only the tadpoles of $P$. cuvieri and L. latrans showed statistically significant reductions in their swimming speed when compared to the control group. The tadpoles of $S$. $x$-signatus presented statistically similar values, although it must be noted that larval development in that species had advanced to phases 39 - 41, when limbs are well developed (Gosner, 1960) and could considerably decrease their swimming ability.

Based on chlorpyrifos toxicity research with amphibians, there are indications that sensitivity to that pesticide is highly species-specific, and influenced by the larval developmental stage of the species (Wildder \& Bidwell, 2006). Those chemical compounds may cause subtle changes over time, with indirect effects on their survival, and make them more vulnerable to natural environmental pressures (Silva et al., 2020a).

Behavioral changes, such as reduced swimming speeds, suggest a neurotoxic effect. Several behavioral effects are known to be triggered in organisms exposed to organophosphate, as that insecticide inhibits acetylcholinesterase and therefore impacts locomotive performance even at low concentrations (Widder \& Bidwell, 2008; Rutkoski et al., 2020; Silva et al., 2020a).

According to Scott \& Sloman (2004) and Relyea \& Hoverman (2006), although tadpole exposure to pesticides does not necessarily cause direct mortality, the resulting modifications of their behavior can indirectly affect their survival, as the reduction of their swimming capacity could result in increased vulnerability to predators, alter important growth and development functions, and also impair their ability to feed.

Plaut (2001), in his investigations of larval phases among amphibians, observed that their swimming ability is the main characteristic determining their survival in aquatic environments, and it may also influence the ability of these animals to obtain the food necessary for their development. Watkins (1996) observed in his study with Pseudacris regilla tadpoles a correlation between swimming ability and predation risks, with slow swimming tadpoles being more vulnerable to predation by water snakes than faster tadpoles.

Although several studies have reported inactivity in tadpoles exposed to organophosphate class pesticides, Peltzer et al. (2013) observed that swimming speed and distance increased at certain concentrations, probably reflecting the fact those levels of acetylcholinesterase inhibition were not sufficient to impact swimming speed. Other researchers reported inactivity and slow tadpole responses when exposed to chlorpyrifos, including in Acris crepitans, Hyla chrysoscelis, Gastrophryne olivacea, R. sphenocephala (Widder \& Bidwell, 2008), X. laevis (Richards \& Kendall 2002; Bonfanti et al., 2004), Ceratophrys ornata (Salgado Costa et al., 2018), Physalaemus gracilis (Rutkoski et al., 2020), and Odontophrynus carvalhoi (Silva et al., 2020a).

In the present study, chlorpyrifos was toxic and had a negative impact on the swimming ability of $P$. cuvieri and $L$. latrans tadpoles at sublethal concentrations. Therefore, chlorpyrifos were evidenced to have negative effects on tadpoles that inhabit agroecosystem pools, making them more susceptible to predation and/or less efficient at foraging.

\section{ACKNOWLEDGMENTS}

We thank the Brazilian Ministry of the Environment for the permit to conduct the study (ICMBio permit no. 27305-1) and the Ethics Committee on Animal Use of the University (CEUAUEFS protocol no. 02/2012). This study was funded by the Brazilian National Council for Scientific and Technological Development (CNPq), PELD: Chapada Diamantina and the Research Support Foundation of the State of São Paulo (FAPESP): SISBIOTA Project: Tadpoles of anurans from the Atlantic Forest, the Amazon, the Pantanal, Cerrado and Transition Zones: Morphological Characterization, Spatial Distribution and Patterns of Diversity (FAPESP proc. 2010/52321-7 and CNPq proc. 563075/2010-4).

\section{REFERENCES}

ANDRADE, C.A.F.; SANTANA, D.J. \& SILVA, S.P.C. 2010. Predation on Scinax x-signatus (Anura: Hylidae) by the giant water bug Lethocerus annulipes (Hemiptera: Belostomatidae) in a Brazilian Restinga habitat. Herpetol. Notes. Volume 3: 053054.

ARCAUTE, C.R., COSTA, C.S., DEMETRIO, P.M., NATALE, G.S. \& RONCO, A.E. 2012. Influence of existing site contamination on sensitivity of Rhinella fernandezae (Anura, Bufonidae) tadpoles to Lorsban ${ }^{\circledR} 48 \mathrm{E}$ formulation of chlorpyrifos. Ecotoxicology. 21:2338-2348. http://dx.doi.org/10.1007/s10646-012-0990-4

BERNABÓ, I., SPERONE, E., TRIPEPI, S. \& BRUNELLI, E. 2011. Toxicity of chlorpyrifos to larval Rana dalmatina: acute and chronic effects on survival, development, growth and gill apparatus Arch. Environ. Contam. Toxicol. 61:704-718. http:// dx.doi.org/10.1007/s00244-011-9655-1

BONFANTI, P., COLOMBO, A., ORSI, F., NIZZETTO, I., ANDRIOLETTI, M., BACCHETTA, R., MANTECCA, P., FASCIO, U., VAILATI, G. \& VISMARA, C. 2004. Comparative teratogenicity of chlorpyrifos and malathion on Xenopus laevis development. Aquat. Toxicol. 70:189-200. http://dx.doi. org/10.1016/j.aquatox.2004.09.007

BOONE, M.D. \& BRIDGES, C.M. 2003. Effects of carbaryl on green frog (Rana clamitans) tadpoles: timing of exposure versus multiple exposures. Environ. Toxicol. Chem. 22: 2695-2702. http://dx.doi.org/10.1897/02-401

BOONE, M.D. \& BRIDGES, C.M. 2006. Examining multiple sublethal contaminants on the gray treefrog (Hyla versicolor): effects of an insecticide, herbicide, and fertilizer. Environ. Toxicol. Chem. 25: 3261-3265. http://dx.doi.org/10.1897/06- 
235R.1

BRIDGES, C.M. 1997. Tadpole swimming performance and activity affected by acute exposure to sublethal levels of carbaryl. Environ. Toxicol. Chem. 16:1935-1939. http://dx.doi. org/10.1002/etc.5620160924.

COLOMBO, A., ORSI, F. \& BONFANTI, P. 2005. Exposure to the organophosphorus pesticide chlorpyrifos inhibits acetylcholinesterase activity and effects muscular integrity in Xenopus leavis larvae. Chemosphere. 61:1665-1671. http:// dx.doi.org 10.1016/j.chemosphere.2005.04.005

DAAM, M. A., MOUTINHO, M. F., ESPÍNDOLA, E. L. G., \& SCHIESARI, L. 2019. Lethal toxicity of the herbicides acetochlor, ametryn, glyphosate and metribuzin to tropical frog larvae. Ecotoxicology, 28, 707-715. http://dx.doi.org/10.1007/ s10646-019-02067-5

DA SILVA, I.L.A. 2006. Monitoração de pesticidas em ambientes de intensa atividade agrícola na região do norte fluminense. Monograph, Universidade Estadual do Norte Fluminense Darcy Ribeiro, Campos dos Goytacazes, 42p.

FERREIRA, R.B. \& TONINI, J.F.R. 2010; Living holed: Leptodactylus latrans occupying crabs' burrows. Herpetol. Notes. Volume 3: 237-238.

GOSNER, K.L. 1960. A simplified table for staging anuran embryos and larvae with notes on identification. Herpetologica. 16:183190.

KIESECKER, J.M., BLAUSTEIN, A.R. \& BELDEN, L.K. 2001. Complex causes of amphibian population declines. Nature 410:681-684. http://dx.doi.org/10.1038/35070552

KRISHNAMURTHY, S.V. \& SMITH, G.R. 2010. Growth, abnormalities, and mortality of tadpoles of american toad exposed to combinations of malathion and nitrate. Environ. Toxicol. Chem. 29 (12):2777-2782. http://dx.doi.org/10.1002/ etc. 331

LAJMANOVICH, R.C., PELTZER, P.M., ATTADEMO, A.M., CABAGNA-ZENKLUSEN, M.C. \& JUNGES, C.M. 2012. Los agroquímicos y su impacto en los anfibios: un dilema de difícil solución. Revista. Quím. Viva. 3:184-198.

LAJMANOVICH, R. C., ATTADEMO, A. M., SIMONIELLO, M. F., POlETtA, G. L., JUNGES, C. M., PELTZER, P. M., GRENÓN, P., \& CABAGNA-ZENKLUSEN, M. C. 2015. Harmful effects of the dermal intake of commercial formulations containing chlorpyrifos, 2,4-D, and glyphosate on the common toad Rhinella arenarum (Anura: Bufonidae). Water Air Soil Pollut., 226, 427. http://dx.doi.org/10.1007/s11270-015-2695-9

LINGNAU, R. 2009. Distribuição temporal, atividade reprodutiva e vocalizações em uma assembleia de anfíbios anuros de uma Floresta Ombrófila Mista em Santa Catarina, sul do Brasil. Tese de Doutorado, Pontifícia Universidade Católica do Rio Grande do Sul, Porto Alegre.

LIPS, K. R.; BURROWES, P. A.; MENDELSON, J. R. \& PARRAOLEA, G. 2005. Amphibian Population Declines in Latin America: A synthesis. Biotropica. 37(2): 222-226. http://dx.doi. org/10.1111/j.1744-7429.2005.00029.x

MANN, R.M., HYNE, R.V., CHOUNG, C.B. \& WILSON, S.P. 2009. Amphibians and agricultural chemicals: Review of the risks in a complex environment. Environ. Pollut. 157:29032927. http://dx.doi.org/10.1016/j.envpol.2009.05.015

MOREIRA, R.A., FREITAS, J.S., DA SILVA PINTO, T.J., SCHIESARI, L., DAAM, M.A., MONTAGNER, C.C., GOULART, B.V. \& ESPINDOLA, E.L.G. 2019. Mortality, Spatial Avoidance and Swimming Behavior of Bullfrog Tadpoles (Lithobates catesbeianus) Exposed to the Herbicide Diuron. Water Air Soil Pollut. 230:125. http://dx.doi.org//10.1007/ s11270-019-4168-z
MAZANTI, L.E. 1999. The Effects of Atrazine, Metolachor and Chlorpyrifos on the Growth and Survival of Larval Frogs under Laboratory and Field Conditions. Ph.D. Dissertation. University of Maryland, College Park, MD, USA.

PADEN, N. E.; SMITH, E. E.; MAUL, J. D. \& KENDALL, R. J. 2011. Effects of chronic 2,4,6,-trinitrotoluene,2,4-dinitrotoluene, and 2,6-dinitrotoluene exposure on developing bullfrog (Rana catesbeiana) tadpoles. Ecotoxicol. Environ. Saf. 74, 924-928. http://dx.doi.org/10.1016/j.ecoenv.2010.12.016

PELTZER, P., JUNGES, C., ATTADEMO, A., BASSÓ, A., GRENÓN, P., \& LAJMANOVICH, R. 2013. Cholinesterase activities and behavioral changes in Hypsiboas pulchellus (Anura: Hylidae) tadpoles exposed to glufosinate ammonium herbicide. Ecotoxicology, 22(7), 1165-1173. http://dx.doi. org/10.1007/s10646-013-1103-8.

PENA, M. F.; HOOPER, E.A.; VON, E.S. \& CRUZ, I. 2003. Método para determinação de resíduos de clorpirifós em alface por cromatografia a líquido de alta eficiência. Pesticidas: R. Ecotoxicol. e Meio Ambiente. Curitiba. 13: 37-44. http://dx.doi. org/10.5380/pes.v13i0.3163

PLAUT, ITAI. 2001. Critical swimming speed: its ecological relevance. Comp. Biochem. Physiol. A. 131. 41-50. http://dx.doi. org/10.1016/S1095-6433(01)00462-7

POUNDS, J.A.; BUSTAMANTE, M.R.; COLOMA, L.A.; CONSUEGRA， J.A.; FOGDEN， M.P.L.; FOSTER， P.N.; LA MARCA, E.; MASTERS, K.L.; MERINO-VITERI, A.; PUSCHENDORF, R.; RON, S.R; SÁNCHEZ-AZOFEIFA, A.; STILL, C.J. \& YOUNG, B.E. 2006. Widespread amphibian extinctions from epidemic disease driven by global warming. Nature 439:161-167. http://dx.doi.org/10.1038/nature04246

RELYEA, R.A. \& HOVERMAN, J. T. 2006. Assessing the ecology in ecotoxicology: a review and synthesis in freshwater systems. Ecol. Lett. 9:1157-1171. http://dx.doi.org/10.1111/j.14610248.2006.00966.x

RICHARDS, S.M. \& KENDALL, R.J. 2002. Biochemical effects of chlorpyrifos on two developmental stages of Xenopus laevis. Environ. Toxicol. Chem. 21:1826-1835. http://dx.doi. org/10.1002/etc.5620210910

RUTKOSKI, C., MACAGNAN, N., FOLADOR, A., SKOVRONSKI, V., AMARAL, A., LEITEMPERGER, J., DORNELES, M., HARTMANN, P., MÜLLER, C., LORO, V. \& HARTMANN, M. 2020. Morphological and biochemical traits and mortality in Physalaemus gracilis (Anura: Leptodactylidae) tadpoles exposed to the insecticide chlorpyrifos. Chemosphere. 250. 126162. http://dx.doi.org/10.1016/j.chemosphere.2020.126162

SALGADO COSTA, C., RONCO, A.E., TRUDEAU, V.L., MARINO, D. \& NATALE, G.S. 2018. Tadpoles of the horned frog Ceratophrys ornata exhibit high sensitivity to chlorpyrifos for conventional ecotoxicological and novel bioacoustic variables. Environ. Pollut. 235: 938-947. http://dx.doi.org/10.1016/j. envpol.2017.12.096

SCOTT, G. R. \& SLOMAN, K. A. 2004. The effects of environmental pollutants on complex fish behaviour: integrating behavioural and physiological indicators of toxicity. Aquat. Toxicol. 68:369392. http://dx.doi.org/10.1016/j.aquatox.2004.03.016

SILVA, M.B., FRAGA, R.E., SILVA, F.L., OLIVEIRA, L.A.A., ROCHA, M.A. \& JUNCÁ, F.A. 2020a. Effects of acute exposure of chlorpyrifos on the survival, morphology and swimming ability of Odontophrynus carvalhoi tadpoles. Ecotoxicol. Environ. Contam. 15(1): 37-42. http://dx.doi.org/10.5132/eec.2020.01.05

SILVA, M.B., FRAGA, R.E., NISHIYAMA, P.B., SILVA, I.S.S., COSTA, N.L.B., OLIVEIRA, L.A.A., ROCHA, M.A. \& JUNCÁ, F.A. 2020b. Leukocyte Profiles in Odontophrynus carvalhoi (Amphibia: Odontophrynidae) Tadpoles Exposed to 
Organophosphate Chlorpyrifos Pesticides. Water Air Soil Pollut. 231:372. https://dx.doi.org/10.1007/s11270-020-04726-4

SILVA, M.B., FRAGA, R.E., NISHIYAMA, P.B., SILVA, I.S.S., COSTA, N.L.B., QUEIROZ, T.S., ROCHA, M.A. \& JUNCÁ, F.A. 2020c. Genotoxic effect of the insecticide Chlorpyrifos on the erythrocytes of Odontophrynus carvalhoi tadpoles (Amphibia: Odontophrynidae). Ecotoxicol. Environ. Contam. 15(1): 9-13. https://dx.doi.org/10.5132/eec.2020.01.02

TU, HT; SILVESTRE, F.; PHUONG, N.T. \& KESTEMONT, P. 2010. Effects of pesticides and antibiotics on penaeid shrimp with special emphases on behavioral and biomarker responses. Environ. Toxicol. Chem. 29:929-938. https://dx.doi. org/10.1002/etc. 99

VENTURINO, A.; ROSENBAUM, E.; CASTRO, A. C.; ANGUIANO, L.; GAUNA, L.; SCHROEDER, T. F. \& D'ANGELO, A. M. P. 2003. Biomarkers of effect in toads and frogs. Biomarkers. 8 (3-4): 167-186. https://dx.doi. org/10.1080/1354700031000120116
WATKINS, T.B. 1996. Predator-mediated selection on burst swimming performance in tadpoles of the Pacific tree frog, Pseudacris regilla. Physiol. Zool., 69:154-167. http://dx.doi. org/10.1016/0022-0981(94)90031-0

WIDDER, P.D. \& BIDWELL, J.R. 2006. Cholinesterase activity and behavior in chlorpyrifos-exposed Rana sphenocephala tadpoles. Environ. Toxicol. Chem. 25:2446-2454. https://dx.doi. org/10.1897/05-522R.1

WIDDER, P.D. \& BIDWELL, J.R. 2008. Tadpole size, cholinesterase activity, and swim speed in four frog species after exposure to sub-lethal concentrations of chlorpyrifos. Aquat. Toxicol. 88:918. https://doi.org/10.1016/j.aquatox.2008.02.008.

YIN, X. H., ZHU, G. N., LI, X. B., \& LIU, S. Y. 2009. Genotoxicity valuation of chlorpyrifos to amphibian Chinese toad (amphibian: anura) by comet assay and micronucleus test. Mutat. Res. 680, 2-6. https://dx.doi.org/10.1016/j.mrgentox.2009.05.018. 